\title{
高層集合住宅の風騒音に関する実測調査と基礎的考察 FULL-SCALE MEASUREMENT AND BASIC STUDY ON WIND NOISE IN HIGH-RISE APARTMENTS
}

\author{
吉岡 清*, 須田健一** \\ Kiyoshi YOSHIOKA and Kenichi SUDA
}

\begin{abstract}
Precedent research on wind induced noise in buildings can hardly be found, so that its physical characteristics and effects on residential amenity still remain uncertain. Authors conducted fullscale measurements on wind noise in four high-rise apartments and discussed on the subjects as follows, 1)relation between Leq of wind noise and mean windspeed, 2) effectiveness of gust factor and wind direction on the relationship between Leq and windspeed, 3) difference in wind noise among rooms and buildings. Also definitions of "Effective Windspeed $V_{e}$ ", "Control Windspeed $V_{c}$ ", and " $N$-value Equivalent Windspeed $V_{N-* *}$ " are presented as quantitave parameters to evaluate its effect on amenity.
\end{abstract}

Keywords : wind noise, high-rise apartment, sound environment, living amenity, aerodynamic noise 風騒音, 高層集合住宅, 音環境, 居住性, 空力音

\section{1.はじめに}

建築物まわりの気流（風）によって発生する音が，そ の内部，あるいは，周辺に居住する人々に及ぼす影響を 明らかにし，その制御法を知ろうという問題設定は，こ れまであまり明確には行われていない。建築史上も，お そらく風によって発生する音に注目し，それに対処した という記録は，近年の高層化建築の出現以前では，見い だし難いものと思われる。これは，かつて我々が確保し てきた住環境が，風によって発生する音が問題となるほ ぞ，厳しい条件下にはなかった，ということであろう。 しかし，近年，都市の高密化が進められた結果，住宅の 高層化, 海岸際への展開と, 風環境的に非常に厳しい領 域への居住域の拡大が余儀なくされる状況にあり，この 風騒音の問題も，しだいに顕在化してきているようであ る。最近のアンケート調査" 騒音の居住性障害を, 上位にランクづけるものも表われ てきており，その存在については徐々に知られてきてい る。しかし, 実際の障害程度について, 公表された例は 見あたらず，特異的な事例，あるいは，強風時には一部 で避けられない要因と考えられてきたようである。

既往の研究事例としては, 類似した問題設定をしてい るものに, Berhault の報告2'があり，主要な風騒音の音 源を列挙してその周波数特性を明らかにした点や，風速
と騒音との比例関係 (6 乗則) を指摘した点などが, 注 目される。しかし，対象建屋が 2 棟亡少なく，近年の我 が国の住宅とは異なる設計条件下での実測值であり，そ のまま参考にすることはできない。また，風や音の変動 性を考慮せず，瞬間值で比較している点などに問題を残 した。板本 ${ }^{31}$, 十倉 ${ }^{4}$, 西村 ${ }^{5)}$ は, それぞれ, ルーバーや バルコニー手すりなど，特定部位を対象として風に起因 する発生音の物理性状を明らかにしている。しかし，そ れら以外の部位からの発生を含めた風騒音全般に対す る,それらの位置つけについては，明らかにされていな い。

本研究は, 住環境の調整に関連する要因としての「風 騒音」の位置づけを明確にし，その影響程度や，重要性 を明らかにすることを第一の目的とし，対策が必要な場 合には，その低減・防止方法を明らかにすることをめざ している。上記したようにこれまでの研究例は極めて 少なく, 既存の実験的, 理論的研究手法が, そのまま, この目的のために適用されるとは考えられない。した がって，まず実測的手法により，風騒音の居住性障害要 因としての実態が明らかにされ，その物理的特徴に関す る概略的知見がまとめられたうえで, 効果的な研究手法 が検討されるべきといえる。本報は，このような考えか ら，これまで筆者らが実施してきた 4 つの高層集合住宅
* 佐藤工業中央技術研究所

** 佐藤工業中央技術研究所
Engineering Research Institute, Sato Kogyo

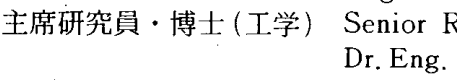


における風騒音の実測調查結果についてまとめ,これま でほとんど知られていない風騒音の物理的特徴の概要に ついてまず考察する。ついで，居住性に及ぼす風騷音の 影響評価をめざした試みとして，風騒音の影響範囲を定 量化するための指標を検討し，実測結果に適用してその 意義を考察する。

なお，「風騒音」という語は，これまで明確に定義さ れていないが，ここでは，風と建築物との関係において 発生する音の総称として用いるものとする。従来,「風 切り音」「笛吹き音」などの語が，発生原理や部位を特 定して用いられてきたが，上記のような問題設定をした ときに，それらを総称する概念が必要と考えたからであ る。また，居住環境に影響する要因としてのとらえ方を 示すため，騷音という語を付して定義する。

ただし，本報の内容は，風を主因とする空力音，気流 音に限定することにする。したがって，風の影響によっ て副次的に発生する「きしみ音」や各種固体衝突音なよ゙ の音（空力音以外の音）は「2 次的発生音」として扱い， 本報でいう「風騒音」とは区別することとする。これは， 2 次的発生音が，それぞれ独自の解決方法を持ち，本報 で設定した問題の解決とは関連性が薄いと考えられるこ とによっている。しかし，「2 次的発生音」であっても， 風とのあいだに強い因果性を持っていたり，「風騒音」 と同様のアプローチが必要な場合なども考えられ，広義 の風騒音の中には，それらを含むものである。本報で述 ベる実測調查は，2 次的発生音や，ある特定部位からの 発生音が卓越することはなく, 発生源が容易に特定でき ない場合のものとした。上記した定義に基づけば，狭義 の風騒音といえる。特定部位からの発生音が卓越した場 合のデータは，本報には含んでいない。

\section{2. ・風騒音の実測方法}

2.1 実測対象建屋

実測対象は，以下の条件を満たすものを選んだ。

(1) 高層集合住宅（軒高が約 $25 \mathrm{~m}$ 以上）であること。

(2) 周囲に風の障害物となる高層構造物がないこと。

（3）交通騒音や工場騒音などの環境騒音レベルがあまり 大きくないこと。

(4) 一般的な建築設計規準に基づいていること。

本報では，図一1，表一1にまとめた 4 つの建屋にお ける実測調查結果について述べる。

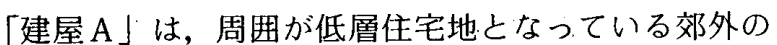
10 階建て集合住宅で, 図一1のように, 雁行型のプラン を持つ。実測時の平均風向は図一1に示すが, 最上階は, 風上側にあたる一住戸分がセットバックしている。「建 屋 B」は, 周囲に開けた草地が続く13 階建ての集合住 宅で,「建屋 $\mathrm{A} 」 に$ 類似した雁行型の平面を持っている。 「建屋C」は, やはり, 周囲が低層住宅地となっている

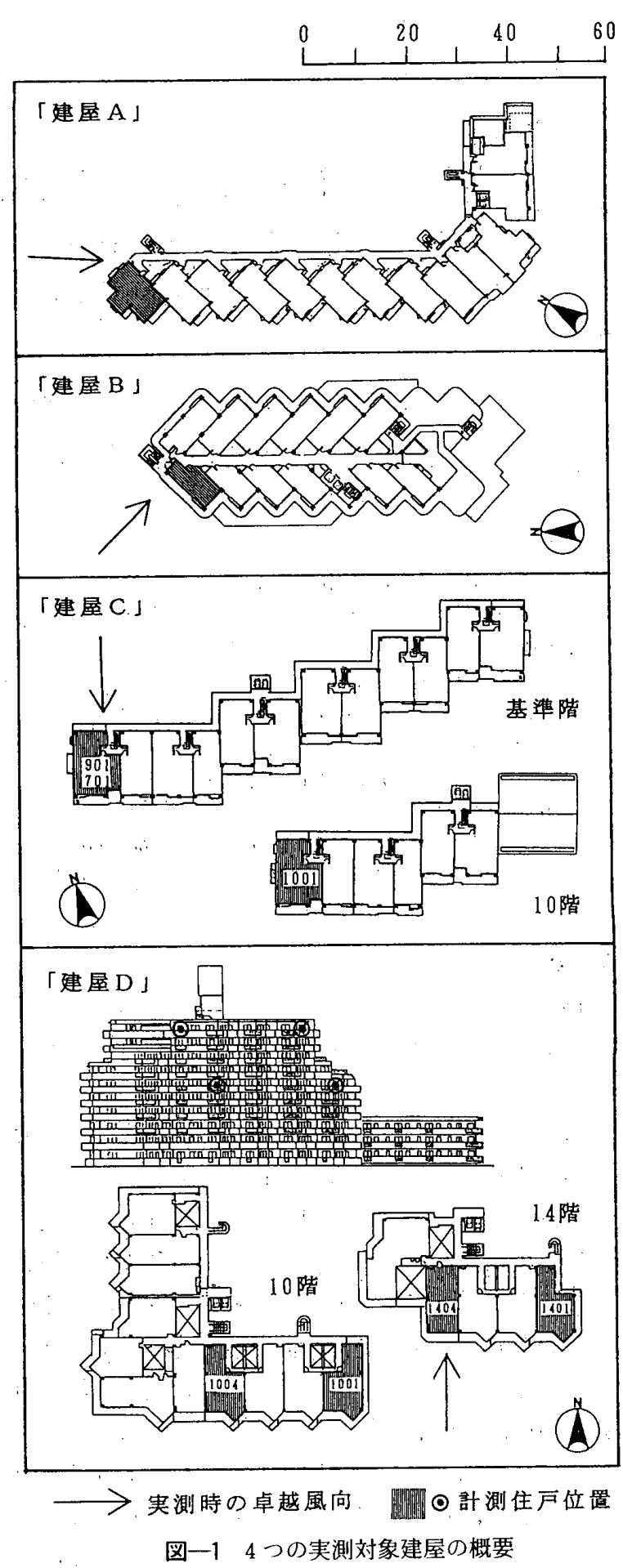

11 階建ての集合住宅で，2 住戸分ずつ雁行した平面形と なっている。立面的には，強風時の風上側（西側）で最 上階一住戸分，東側では，8階レベルより 2 住戸分ずつ， セットバックしている。「建屋D」は，海岸線より約 50 $\mathrm{m}$ 離れた位置にある 14 階建ての集合住宅であるが，地 盤面の高さが変化しているため, 強風時の実測を行った 南面の軒高は約 $29 \mathrm{~m}$ 程度となっている。

いずれの建屋でも，居室に面してバルコニーがあるこ とや，アルミ製サッシュ（JIS A 4706 に基づく気密性 2 等級を満たすもの)，を用いていること，外壁には空調 配管用や換気用のスリーブがあること（実測時には開鎖 
表一1 実測建屋の概要

\begin{tabular}{|c|c|c|c|c|}
\hline 建屋 & 階数 & $\begin{array}{l}\text { 軒高 } \\
\text { (m) }\end{array}$ & $\begin{array}{l}\text { 風速計 } \\
\text { 高さ(m) }\end{array}$ & 計測住戸 \\
\hline A & 10 & 25 & $9.4^{x}$ & 9階 \\
\hline B & 13 & 39 & 46 & 13 階 \\
\hline \multirow[t]{3}{*}{$\mathrm{C}$} & 11 & 32 & 38 & 7階 (701号室) \\
\hline & & & & 9階 (901号室) \\
\hline & & & & 10階(1001号室) \\
\hline \multirow[t]{2}{*}{$\mathrm{D}$} & 14 & 29 & 40 & 10階 $(1001,1004$ 号室 $)$ \\
\hline & & & & 14階 (1401, 1404号室) \\
\hline
\end{tabular}

*)建屋頂部高さ（27m）に補正して使用。

状態とした）など類似点がある一方で, 室内の細部や悹 面積, バルコニーの詳細など, 建屋ごとで異なった条件

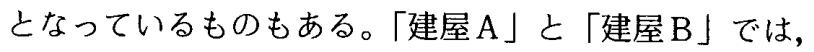
図一1の各 1 室を測定対象亡した。「建屋C」の 3 つの 対象住戸は, 平面的に同一の位置にあり, サッシュの気 密性や室内の仕上げなど, 建築仕様が同一である。「建 屋D」の 4 つの対象住戸は, サッシュの気密性と室内の 仕上げは同一であるが，室の大きさは異なる。

2.2 風向・風速の実測

「建屋 A」では, 建屋から南西の方向約 $1 \mathrm{~km}$ にある 消防署屋上に設置されたプロペラ型風向風速計の記録を

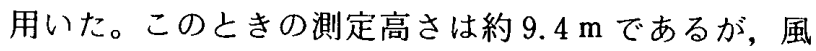
速の鉛直分布にべき乗則（べき指数 0.3）を仮定して, 建屋頂部高さ $(27 \mathrm{~m})$ の平均風速に換算した。消防署 付近も低層住宅地であり,このデータによって, 代表流 れが把握されているものと判断した。「建屋 B」では, ペントハウス上部に熱線式流速計（リオン製 AM-20) を設置して風速をデータレコーダに収録した。センサー の位置は, 建屋の最高高さ点 (ペントハウス上端) から 約 $2 \mathrm{~m}$ の高さとした。この実測では, 強風時にのみデー 夕を収集したが, その間に風向の変化はほとんど無かっ た。「建屋 C」と「建屋 D」では, ペントハウス上部に, 光電式風向風速計（牧野応用測器製 VF 216 および $\mathrm{AF}$ 860）を設置し, 評価時間内の平均風向 - 風速, 瞬間最 大風速およびそのときの風向を記録した。センサ一部は, 最高高さ点（ペントハウス上端）より約 $1.5 \mathrm{~m}$ 上部に 位置するようにした。なお，以下の結果では，测定住戸 の高さが異なる場合も, 風速の高さ補正はせず，上記し た建屋頂部での風向・風速で表わしている。

\section{3 風騒音の実測}

様々な部位からの発生音が重畺された総量的な騒音之 しての風騒音の特性把握を目的とし, その時間平均的な 性状までを対象としたため, 主として居住域内，すなわ ち，居間や寝室内で騒音を測定した。強風時の風騒音の
影響が顕著と考えられる住戸（風上側の最上階の住戸な ど）を選定し，風向側の室の中央に騒音計を設置して測 定した。マイクロホン高さは $1.3 \mathrm{~m}$ とした。

「建屋A」では，騒音計（リオン製 NL-01）の自動测 定機能により, 毎正時 10 分ごとの等価騒音エネルギー レベル $L_{\mathrm{ea}}$, 時間率騒音レベルおよび最大・最小騒音レ ベルを計測した。いずれも $\mathrm{A}$ 特性での值とした。「建屋 $\mathrm{B} 」$ では, 騒音計の出力を流速計の出力とともにデータレ コーダーに収録した。「建屋C」と「建屋D」では，才 クターブバンドの実時間分析機能つき騒音計（リオン製 NA-29）を用いて，10分間ごとのオクターブバンド $L_{\mathrm{eq}}(31.5 \sim 8000 \mathrm{~Hz})$ および A 特性, 平坦特性の全帯 域 $L_{\mathrm{eq}}$ を連続記録した。

このように，建屋ごとで異なる計測法を用いたのは， 風騒音の実測のために確立された方法がなく, 初期の実 測（建屋A，B）で用いた方法を改善する形で, 計測法 を検討する必要があったことによっている。

なお，実測は，建物の新築工事期間中の最終時期，す なわち, 建屋の内装を含めたすべての工事がほぼ終了し， 各住戸の居住者が入居する前の状態を利用して行った。 したがって，住戸内には家具などは設置されておらず， 計測中に, 隣戸や上下階の発生音, あるいは, 居住者自 らが発する音などの影響は含まれない。また，このよう な実測期間の制限があったため, 各建屋での実測時の風 向は, 限られたものでり, 本報で示すデータは, 図一1 に示した風向のものである。

\section{3. 風騒音の実測結果と考察}

\section{1 風騒音の存在}

図一2 は,「建屋C」の 10 階住户（1001 号室）におけ る室内騒音と, 建屋頂部風速の時間変化を示したもので ある。騒音は, 北側のコンクリート手すりつきバルコニー に面した室内で計測した平均時間 10 分のA特性および 平坦特性の $L_{\mathrm{eq}}$ で表示している。風速は, 同じ平均時間 の平均風速 $V_{\text {mean }}$, および瞬間最大風速 $V_{\max }$ を表示し ている。約 3 日間にわたる連続計測の結果であるが, こ の中には，ほぼ北を中心として風向が一定した強風の部

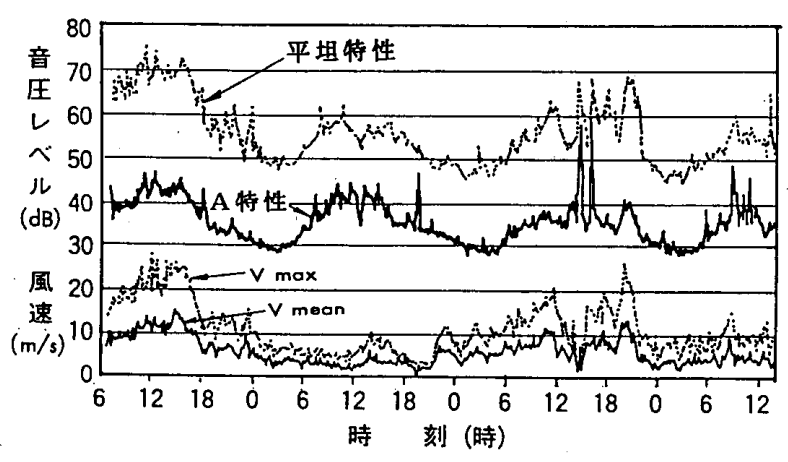

図-2 室内騒音之風速の時間変動の測定例 (建屋 $\mathrm{C}, 10$ 階住戸) 


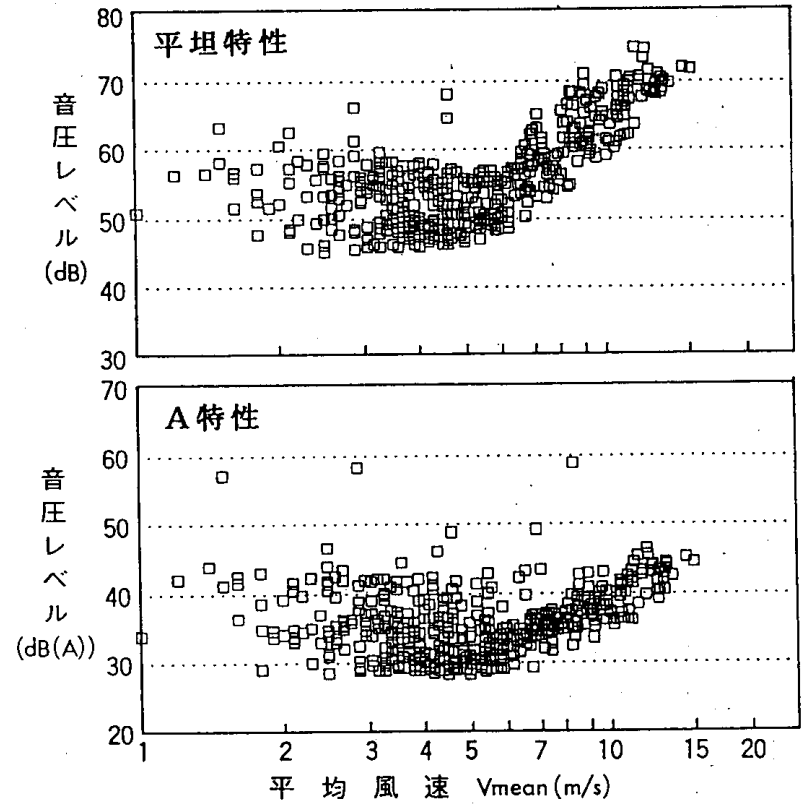

図一3 室内騒音と平均風速の関係 (建屋 C, 10 階住戸)

分が含まれている。また，交通騷音や住戸近辺の人為的 騷音もそのまま含まれている。

これを見ただけでも，風速の増减にともなって， $L_{\mathrm{eq}}$ が増减する部分が認められ, 両者の強い相関, すなわち, 風によって発生していると考えられる騒音の存在が確認 できる。これをもっと詳しく検討するため,この実測值 のすべてを, 横軸に平均風速 $V_{\text {mean }}$ の対数, 縦軸に $L_{\mathrm{eq}}$ をとった散布図の上にプロットすると図一3のように なった。図一 3 では， $L_{\mathrm{eq}}$ と $V_{\text {mean }}$ との間に相関のある 部分（高風速域）とそうでない部分（低風速域）が区別 でき, 前者は風によって発生する音, すなわち風騷音を プロットしたものであり，後者は，それ以外の音，すな わち,この室における交通騒音などの暗騷音をプロット したものと考えられる。

以上の上うな風騷音の存在を示す測定結果は, 4 つの 建屋のすべてにおいて確認された。風騒音の大きさは, 風速とともに増大するが, 図一 3 では, 平均風速 $15 \mathrm{~m} / \mathrm{s}$ のとき, $45 \mathrm{~dB}(\mathrm{~A})$ を越える大きなものとなっている。

\section{2 室内の風騒音と平均風速の関係}

（1）風騒音の $L_{\mathrm{eq}}$ と平均風速の関係に関する実測結果 図一4は，「建屋D」におけるオクターブバンドごと の $L_{\mathrm{ea}}$ と $V_{\text {mean }}$ の関係を示したものである。10分平均 風速が 8 25 $\mathrm{m} / \mathrm{s}$ の強風時のデータに限定して示してい る。図一 3 よりも非常にデータの相関がよく, $E \propto V_{\text {mean }}{ }^{\alpha}(E:$ :室内騒音の音響エネルギ一密度 $)$ の関 係,すなわち,「べき乗則」が確認できる。べき指数 $\alpha$ は, 平坦特性で 4 室ともほぼ 5.5 , A 特性ではそれより大き く, 6〜7となっている。また，参考として，オクター ブバンドごとでの $\alpha$ をみると, $5 \sim 6$ の值を中心として, 4〜6の範囲にばらつく結果となっている。ただし，4 室 とも $2 \mathrm{kHz}$ ではほぼ7, $4 \mathrm{kHz}$ では $8 ９$ の大きな值と
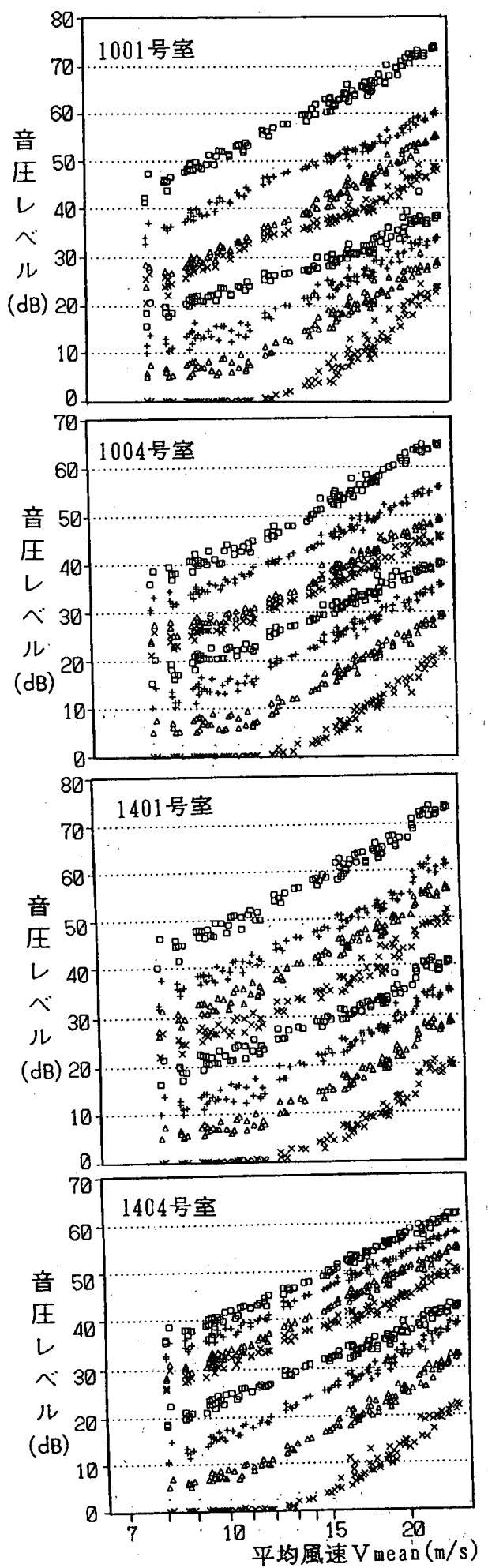

$31.5(\square) 、 63(+), 125(\Delta) 、 250(x) 、 500112-5 \mathrm{~dB}(\square)$ $1 \mathrm{kHz}-10 \mathrm{~dB}(+) 、 2 \mathrm{k}\|z-15 \mathrm{~dB}(\Delta) 、 4 \mathrm{k}\| z-20 \mathrm{~dB}(X)$

図一4 強風時の風騒音と平均風速の関係（建屋 $\mathrm{D})$

なっている。

強風時の風騒音におけるこのような「べき乗則」は, 4 つの建屋のすべてにおいて確認されたが, A特性およ び平坦特性でのべき指数の観測值は, 建屋・室ごとで異 なり,3〜7の值となった。

また, 1001 号室の $250 \mathrm{~Hz}$ や $500 \mathrm{~Hz}$ など, べき乗則 
に対する回帰直線の定数項がある風速值の前後で変わる 場合が認如らる。これに類似した風騒音のやや複雑な 変動性状は, Berhault の報告にもみられるが, 以下では, 概略的な傾向をつかむため，上記した「べき乗則」に注 目して回帰直線を求め, 考察を進めている。

\section{（2）風騒音の平均方法}

風騒音は，風の条件に対応して変動する騒音であるた め，その物理性状を評価するためには，時間軸上の平均 操作が不可欠となる。これまで，風騒音を風との関係に おいて平均するための適当な方法とその裏付けについて 検討された例はない。ここでは，風と風騒音の時間平均 を代表する值として，何が適当かについて検討する。

空力音響学によれば，気流の涌き出し，変動力, 内部 粘性応力に対応して, 音響単極子, 双極子, 四重極子が 形成され，代表流速 $V$ とそれぞれの音響出力 $W_{M}, W_{D}$, $W_{Q}$ との間に，次のべき乗則が成立する6!。

$$
\begin{aligned}
& W_{M} \propto \rho V^{4} L^{2} / c \\
& W_{D} \propto \rho V^{6} L^{2} / c^{3} \\
& W_{Q} \propto \rho V^{8} L^{2} / c^{5}
\end{aligned}
$$

ここに， $\rho$ は流体の密度， $L$ は代表長さ， $c$ は音速であ る。

しかし，本報でいう風騒音は，単一の音源だけを対象 とするのではなく，様々な部位で様々な発生機構で発生 する音が重畳されたものを対象としていることから，発 生機構に応じたべき指数を持つべき乗則を仮定すること は適当ではなく，(1a)～(1c) 式のような単純な関係は 成り立たないと考えられる。しかし，前述のように，風 騒音の実測值は，ほほべき乗則に従っているものと見ら れる。そこで, 各瞬間における室内の音響エネルギ一密 度 $E(t)$ と代表流速 $V(t)$ との間に，(2) 式の関係が成 り立つものと仮定して， $E$ と $V$ の時間平均値の間に成 り立つ関係について考察する。

$$
E(t)=K \cdot V(t)^{\alpha} \text {. }
$$

ここに, 比例定数 $K$ は, 発生音の強度, 受音点までの 伝搬性状を総合的に表す係数で, 建屋や室, あるいは, 風の条件などの関数と考えられる。

$E$ の時間平均値として， $L_{\mathrm{eq}}$ を用いると，（3）式と なる。

$$
\begin{aligned}
L_{\mathrm{eq}}(t) & =10 \log \frac{1}{T} \int_{t-T / 2}^{t+T / 2} E(\tau) / E_{0} d \tau \\
& =10 \log \frac{1}{T} \int_{t-T / 2}^{t+T / 2} K \cdot V^{\alpha}(\tau) / E_{0} d \tau
\end{aligned}
$$

$V(t)$ にはエルゴード性が仮定できるとすると，

$$
=10 \log \int_{v_{1}}^{v_{2}} P(V) \cdot K \cdot V^{\alpha} / E_{0} d V
$$

となる。ここに, $T$ は平均時間, $E_{0}=10^{-12}(W),\left(v_{1}, v_{2}\right)$ は， $P(V)$ の定義域である。また， $P(V)$ は，風速が $V$ となる確率密度を表わし, 自然風ではある程度大きな $T$ に対して，（5）式のガウス分布に従うと仮定してよ $\left(^{\eta)}\right.$

$$
P(V)=\frac{1}{\sqrt{2 \pi} \sigma} e^{-(V-\mu)^{2} / 2 \sigma^{2}} \quad(-\infty<V<\infty)
$$

（5）式を用いて（4）式を計算すると,

$$
\begin{aligned}
L_{\mathrm{eq}} & =10 \log \int_{-\infty}^{\infty} \frac{K}{\sqrt{2 \pi} \sigma} \cdot e^{-x^{2} / 2 \sigma^{2} \cdot(x+\mu)^{\alpha} / E_{0} \cdot d x} \\
& =10 \alpha \log \mu+L_{k}+L_{\mathrm{cor}} \cdots \cdots \cdots \cdots \cdots \cdots \cdots(6) \\
L_{k} & \equiv 10 \log K / E_{0} \cdots \cdots \cdots \cdots \cdots \cdots \cdots \cdots \cdots \cdots \cdots(7) \\
L_{\mathrm{cor}} & \equiv 10 \log \left[1+\left(\begin{array}{c}
\alpha \\
2
\end{array}\right)\left(\frac{\sigma}{\mu}\right)^{2}+3\left(\begin{array}{c}
\alpha \\
4
\end{array}\right)\left(\frac{\sigma}{\mu}\right)^{4}+\cdots\right]
\end{aligned}
$$

となる。ここで， $\alpha \in$ Natural とした。（6）式の第 1 項 および第 2 項は, $V$ の集合平均 $\mu$ と $L_{\mathrm{eq}}$ との間のべき 乗則を示しているが，これに，第 3 項，（8）式に示す ような修正項がついていることに注意を要する。以降, (6) （８）式の $\mu$ (集合平均) を $V_{\text {mean }}$ (時間平均) に置き換えて用いる $(V(t)$ のエルゴード性より)。

（8）式の $L_{\text {cor }}$ は, 風速の乱れの強さ $\left(\sigma / V_{\text {mean }}\right)$ お よび $\alpha$ の関数であり，このことから，風騒音の $L_{\mathrm{eq}}$ は 変動風の乱れの強さの関数ともなっていることが分か る。 $\sigma / V_{\text {mean }}$ が $V_{\text {mean }}$ に依存せず一定と考えられる場合 には，修正項 $L_{\text {cor }}$ の $V_{\text {mean }}$ に対する依存性がなくなり， べき乗則の定数項 $L_{k}$ 之，観測上区別がつかなくなる。 このとき， $L_{\mathrm{eq}}$ と平均風速とのあいだには， $\alpha$ をべき指 数とし $L_{k}+L_{\mathrm{cor}}$ を定数項としたべき乗則が成立する。

自然風に関する既往の研究によると, $\sigma / V_{\text {mean }}$ の值は, 低風速域では多少大きめの值になるが，風による様々な 影響が生じ始める高風速域では, 地表面の粗度や観測高 さによって，ほぼ一定した值になることが知られてい る7。通常の建物が建設される粗度や高さにおいては, $T=600 \mathrm{sec}$ の場合, $\sigma / V_{\text {mean }}=0.1 \sim 0.3$ 程度の値にな るとされているため7, $L_{\mathrm{cor}}$ の値は, 図一5 のようになる。

以上より，（2）式が仮定できるとき, 変動風の代表 值として平均風速を用い，風騒音を $L_{\mathrm{eq}}$ で評価すれば, 時間平均に対してもべき乗則が成り立つことが分かる。 このとき, べき乗則のべき指数 $\alpha$ と定数項 $L_{k}+L_{\mathrm{cor}}$ に

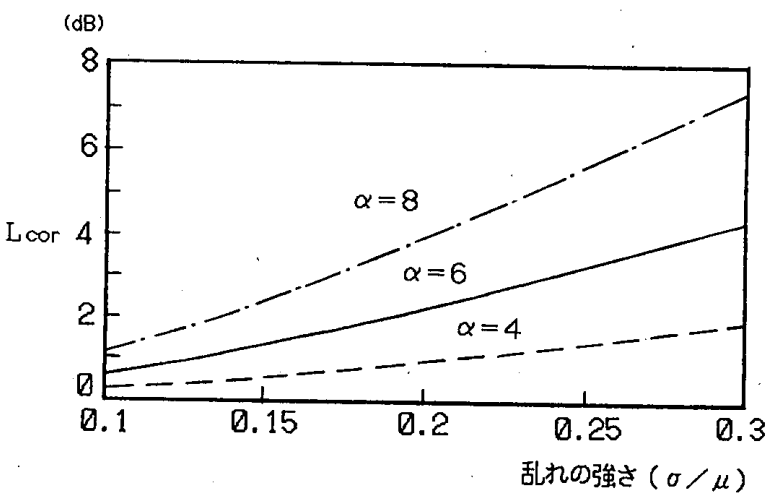

図一5 ベき乗則に対する補正項 $L_{\mathrm{cor}}$ の值 
よって，風騒音と風速の関係が整理できることになる。 $\alpha$ は風騒音の発生機構に関連するパラメータであり，定 数項は, 発生源の数や強度, あるいは伝搬経路上の減衰 性状を総合的に表わした $L_{k}$ と, 風の乱れの強さに応じ た值を持つ $L_{\text {cor }}$ の和となっている。

平均時間 $T$ は, $P(V)$ の分布や乱れの強さに影響する 因子として位置づけられる。風騒音の実測にあたり, 適 当な平均時間を設定せねばならないが, 本報では $T=$ $600 \mathrm{sec}$ を標準的なものと考えることにした。その理由 は，わが国の気象官署による風観測において，この平均 時間が一般的に用いられており，多くのデー夕の蓄積が あること，および，音環境の評価時間としても適当な長 さを持っていること, さらに，この時間内において風速 が（5）式で表わされるガウス確率過程に従うと考えら れていること,などである。もちろん，音環境評価とい う観点から，より長時間にわたる $L_{\mathrm{eq}}$ や他の指標に変換 することが有効になる場合も考えられる。

なお，（1）式のべき乗則は，音の全帯域值について 成り立つものであり，オクターブバンドごとには成立し ない。これは，ある特定の発生機構にのみ注目すれば， 風速が変わることにより卓越周波数がバンド間を移動す る現象が生じるためである。一方，音環境計画の観点か らは，周波数帯域別の音場の把握は必須の条件であり， 風騒音の物理性状も，オクターブバンドごとで評価され ることが望ましい。このような観点から図一4の結果を 見ると, 各オクターブバンドごとでも, 上記したべき乗 則が十分精度良く成立していることが分かる。これは， 本報でいう風騒音が,単一の発生音によるものではなく， 多数の音源からの寄与が重且された音場であると考えら れることを示すものである。

\section{3 風騒音におよばす変動風パラメータの影響}

風騒音の $L_{\mathrm{eq}}$ と平均風速 $V_{\text {mean }}$ のあいだには，（6) 式のべき乗則が成り立ち, 実測結果も，これに基づいて 整理されることが分かった。ここでは, 実測結果への( 6$)$ 式の適用性をより詳しく知るため, 実測結果に含まれる 平均風速以外の, 乱れの強さなどの風の変動性の影響が どれほどであるかの検討を行った。

まず，風の乱れの強さより，より一般的に観測されて いる評価時間内の瞬間最大風速 $V_{\max }$ を用いたパラメー タのガストファクタ $G$

$$
G=V_{\max } / V_{\text {mean }}
$$

を求めて，風の乱れの影響に関する考察を進める。G の集合平均は, 風の乱れの強さ $\sigma / V_{\text {mean }}$ の集合平均之, 一義的関係にあると考えられる ${ }^{7}$ 。また, 観測時間内の 風向の分散のようなパラメータも, 風の変動に関連して, 重要と考えられるが，あまり一般的に計測されていない ため,ここでは, 平均風向 $D$ の卓越風向（測定期間中 の最頻風向）からのずれを用いて；風騒音に及ぼす影響
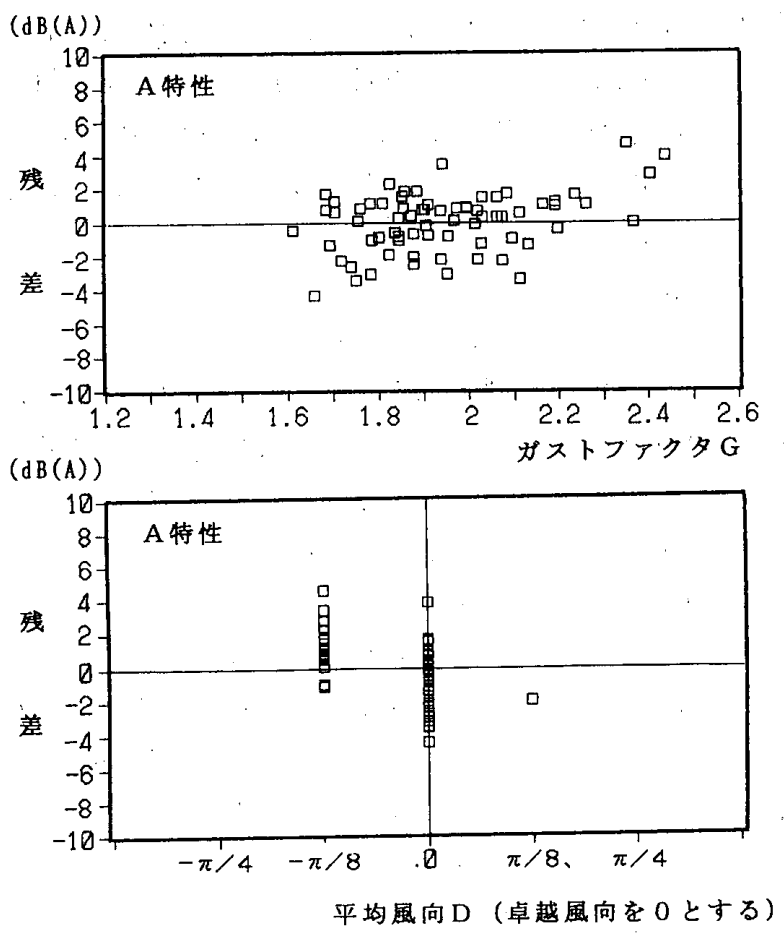

図一6 風騒音の回帰式の残差とガストファクタ，平均風向の関 係 (建屋C,10 階住戸)

を検討した。平均風向が大きく異なれば，当然風騒音は 変化すると考えられるため,ここでは, 測定期間中の最 頻風向付近の風のみを対象亡したときの, 最頻風向から のわずかな風向の偏差が，風の変動性を代表して風騒音 に関係するかを検討することとした。したがって，平均 風向 $D$ は, 測定期間中の最頻風向を 0 とし, 時計方向 に正の数值を与える方法で数值化し， $-\pi / 8 \sim \pi / 8$ には いるデータのみを対象として解析した。なお，実測建屋 の周辺状況は，方位によって同一とみなせるため， $G$ は $D$ に対して独立な変数と考えた。

実測值の $L_{\mathrm{eq}}$ と $V_{\text {mean }}$ との間には, 図一 3,4 に示し たようなべき乗則が観測され，散布図上に（6）式と同 じ形をした回帰直線

$$
L_{\mathrm{eq}}=c_{0}+c_{1} \cdot \log V_{\text {mean }}
$$

が引けるが，これと各データとの残差を，Gおよび $D$ をパラメータとして表示すると, 図一6のようになった。 これより，残差は，まだランダムとなっておらず，G や $D$ に対する依存性が諗められる。これを確認するた め, 重回帰分析により, 目的変数 $L_{\mathrm{eq}}$ に対する説明変数 として, $V_{\text {mean }}$ 以外に $G$ や $D$ を加えることが有効かど うかの検定を行った。このとき，重回州式として，(10) 式を用いた。

$$
L_{\mathrm{eq}}=c_{0}+c_{1} \cdot \log V_{\text {mean }}+c_{2} \cdot G+c_{3} \cdot D \cdots \cdots(10)
$$

$G$ や $D$ の有効性が; 周波数帯域や, 平均時間, 室位 置などによって，どう異なるかを見るため，オクターブ バンドごとの $L_{\mathrm{eq}}$ を対象とし，「建屋C」における 7，9， 10 階の風上側住戸での測定値を用いた。 
表一2 ガストファク夕の有効性の検定結果

\begin{tabular}{|c|c|c|c|c|c|c|c|}
\hline \multirow[b]{2}{*}{ 室番号 } & \multirow[b]{2}{*}{ 平均時間 } & \multicolumn{6}{|c|}{ オクターブパンド中心周波数 (Hz) } \\
\hline & & 31.563 & 125250500 & $1 \mathrm{k}$ & $2 \mathrm{k}$ & & $B(A)$ \\
\hline 1001 & 10分 & 00 & 000 & 0 & $\mathrm{O}$ & 0 & 0 \\
\hline 1001 & 2分 & 00 & 000 & 0 & 0 & 0 & 0 \\
\hline 1001 & 1 & - & -0 & - & - & 0 & - \\
\hline 901 & 10 & 00 & 000 & 0 & 0 & 0 & 0 \\
\hline 701 & 2 & - & 00 & - & - & 0 & - \\
\hline 701 & 1 & - & - & - & - & - & - \\
\hline
\end{tabular}

○ 有意水準5\%で有意

表一3. 風向の有効性の検定結果

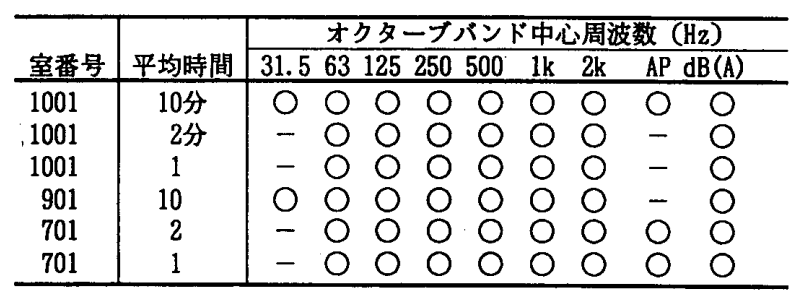

\section{○ 有意水準5\%で有意}

表一2，3に解析結果を示す。これより，ガストファ クタは平均時間により有効性が変わり, $T=60 \mathrm{sec}$ 程度 の短い平均時間では有効でないのに対して, $T=600$ $\sec$ 程度の平均時間では有効であることが分かる。ただ し, 特定の建屋（特定の地点に立つ建築物）を対象とし た場合は，夷現される $G$ の範囲が限定されるため，本 例のように， $G=1.7 \sim 2.2$ (実測値の $80 \%$ が入る範囲 に相当）まで変化したとしても，ガストファクタの影響 度は, $2 \mathrm{~dB}$ 以下の差異が生ずるだけの小さなものとなっ ている。また,「建屋D」における実測結果でも, ガス トファクタの影響程度は最大 $2 \mathrm{~dB}$ 程度となった。

一方, 平均風向 $D$ は, $31.5 \mathrm{~Hz}$ などの低音域で有効 でない結果を与える場合がみられるほか，ほぼどの条件 でも説明変数として有効という結果である。平均風向の 影響程度は， $D=0 \sim \pi / 8$ まで変化しても $2 \mathrm{~dB}$ の差異が 生ずるだけの小さなものとなっている。「建屋 D」では, 強風時の風向は一定していたため，この分析は行わな かった。

以上より, 実測結果からも風の変動性状が風騒音に影 響することが確認された。ただし，その影響程度は，特 定建屋を対象とした場合には，あまり大きなものではな いことが示され，風騒音の評価上風の変動性状をどこま で詳しく把握しておくべきかに対する示唆を与えてい る。すなわち，建築的条件を含めた他の要因による効果 を精度良く予測可能となった時点で，これらの変動風パ ラメータを考慮すれば良いものと考えられる。このよう な主旨から, 以降では $G$ や $D$ の効果を考虑しない単回 帰式（( 9$)$ 式）で実測結果を代表するものとする。 3.4 同一建屋内の室位置による風騒音の差異

風騒音に及ぼす建築側の条件の影響を見るため,まず， 同一建屋内の異なる室における風騒音の比較を行う。図 一7は,「建屋C」の 3 室の $L_{\mathrm{eq}}$ を比較したものである。

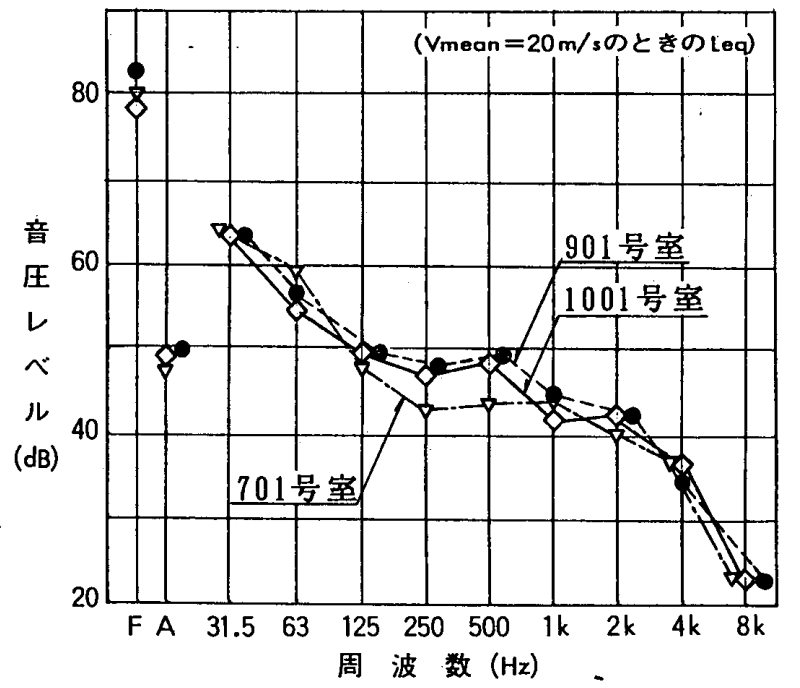

$\mathrm{F}$ ：平坦特性 $\mathrm{A} ： \mathrm{~A}$ 特性

図一7 同一建屋内の室位置による風騒音の差異（建屋C）

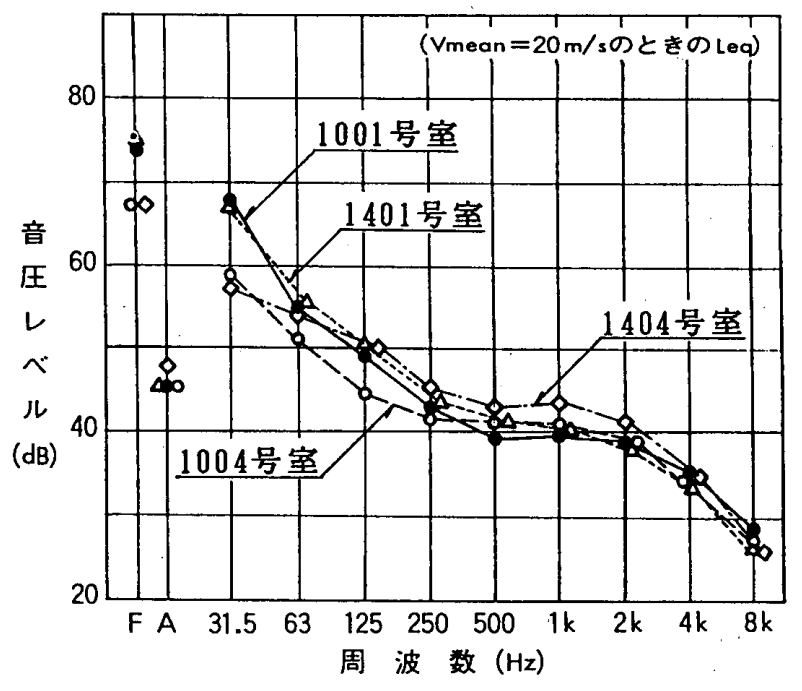

$\mathrm{F}$ : 平坦特性 $\mathrm{A}$ ： A 特性

図一8 同一建屋内の室位置による風騒音の差異（建屋 D ）

$3.2 ， 3.3$ で述べたオクターブバンド $L_{\mathrm{eq}}$ と $V_{\text {mean }}$ の回 帰式を, それぞれの室で求め $V_{\text {mean }}=20 \mathrm{~m} / \mathrm{s}$ を代入した ときに得られたものである。図一8は，同様の比較を「建 屋D」の 4 室で行ったものである。

図一7をみると, 1001 号室と 901 号室では差異は小さ く, 701 号室は, これらと比較して, $250 \mathrm{~Hz}$ と $500 \mathrm{~Hz}$ で約 $6 \mathrm{~dB}$ の差異があるほかは， $3 \mathrm{~dB}$ 以下の差異になっ ている。図一8では, 東側端部住戸の 1001 号室および 1401 号室の結果が, 高さが異なるにもかかわらず，ほ ぼ同等になっており, 最大でも $2 \mathrm{~dB}$ 以下の差異になっ ている。建屋端部の最上階より下層 4 階程度では, あま り大きな差異が生じないことがわかる。

\section{5 建屋による風騒音の差異の概略的傾向}

図一9は,「建屋A」から「建屋 D」における実測結 果を比較したもので，A特性と平坦特性のべき乗則を仮 
( d B)

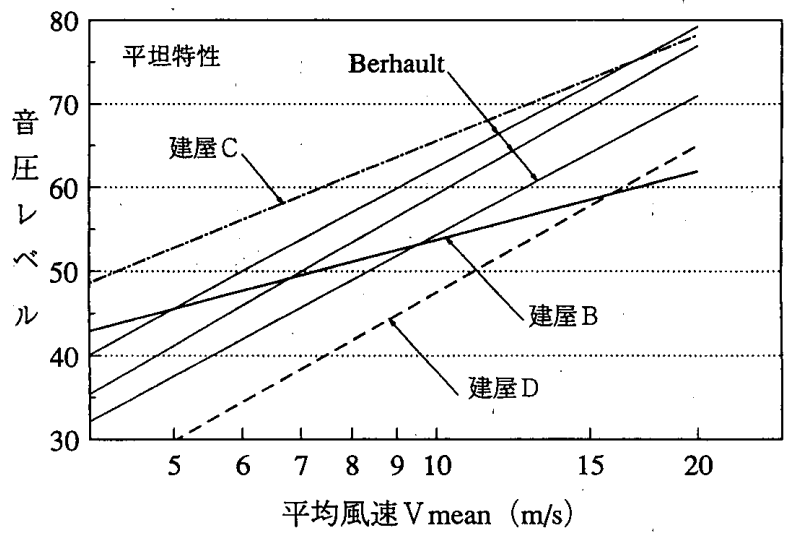

( d B)

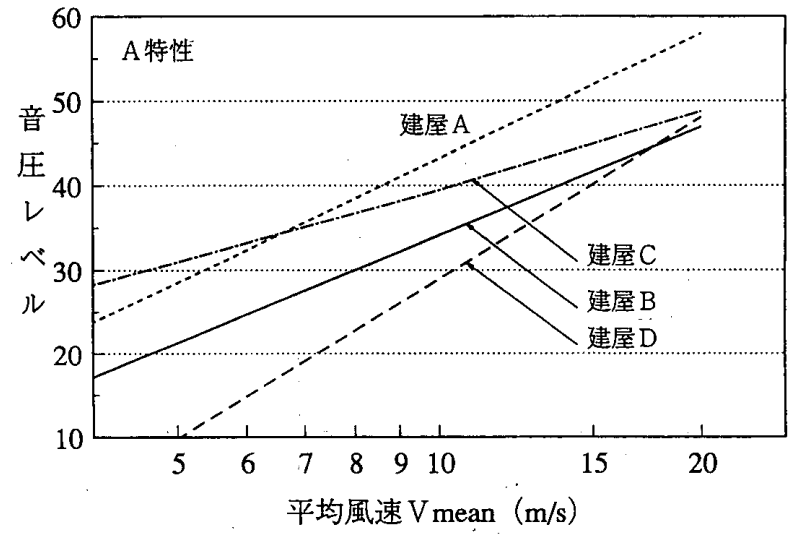

図一9 風騷音の建屋による差異の比較（建屋C は 1001 号室, 建屋Dは1401 号室)

定した回帰直線（( 9 ）式）で表示している。「建屋A」 は，平坦特性での実測を行わなかったため，A特性の結 果のみ示している。同一建屋で複数の室の実測を行った 場合には，最上階風上側などの最も風騒音が大きくなっ た測定結果で建屋の代表とした。すなわち「建屋C」は 1001 号室,「建屋D」は1404 号室で代表した。また参 考として, Berhault の実測值 ${ }^{2}$ ( 平坦特性) も併せて示 した。各建屋とも, 強風時の単一の風向に対する実測結 果であり，建屋と風向との関係はそれぞれで異なってい る。

これを見ると， $V_{\text {mean }}=10 \mathrm{~m} / \mathrm{s}$ の場合に，最大のもの と最小のものとで, 平坦特性で $18 \mathrm{~dB}, \mathrm{~A}$ 特性で $14 \mathrm{~dB}$ (A) の差異となっている。

これらの結果は, 風騒音の発生側の条件（風の条件お よび建築配置, 外形なざ）と音の伝般上の条件（建築外 皮の遮音性や室内の吸音性など）のそれぞれに基づいて 生じた風騒音の差異を，総合してその総和として比較し たものであり，個々のどの条件によるものであるかは， ここでは判別できない。しかし，これらの条件が変わる ことによる風騒音の差異が，実際によ゙れほどのものであ るかの一端を示している。

\section{4. 風騒音の居住性におよぼす影響評価のための指標}

\section{1 風騒音の影響風速上支配風速}

風騷音の居住性におよぼす影響を示し評価するために は, 強風時におけるその物理性状を知ることも重要であ るが、風騷音の影響がおよぶ範囲や条件を明らかにする ことも,これと等しく重要な課題と考える。したがって, 前章で示したように，べき乗則のべき指数や定数項によ り強風時の風騒音を定量化することに加えて，適当な指 標を用いて，風騒音の影響範囲や程度を定量化すること も課題になる。

図一2，3に，強風時の風騒音の部分を含んだ約 3 日 間にわたる室内騒音の実測結果を示したが，これに類似 した結果は，各建屋において得られた。したがって，室 内における騷音の $L_{\mathrm{e}} \mathrm{a}$ 亡風速の関係は, 図一3を一般化 して示した図一10のようになると考えられる。図-10 には，室内の音環境に対する風騷音の影響の現われ方が 示されている。すなわち, 室内の $L_{\mathrm{eq}}$ と風速との間に相 関のない低風速の領域があり，これより大きな風速にな ると， $L_{\mathrm{eq}}$ が風速に対応したある一定レベル以下に下が らないようになる。そして，さらに高風速域では， $L_{\mathrm{eq}}$ と風速との間に強い相関がみられるようになり，前章で 示したべき乗則が成立するようになる。これらの 3 つの 領域は, 図一10の 2 つの風速值 $V_{e}, V_{c}$ により区分で きる。 $V_{e}$ 以下では, 風騒音の発生が弱いため, $L_{\mathrm{eq}}$ は 風速之無関係に分布して, 室内の暗騒音の変動範囲を示 しているのに対し， $V_{e}$ 以上では風騒音の発生がより強 くなると考えられ，これが室内暗騒音の最低レベルを超 えて影響をおよぼし始めると考えられる。さらに高風速 域の $V_{c}$ 以上では, 風騒音が主要な音源になり, 室内の 音環境を支配するようになる。この意味で, $V_{e} \leqq V_{\text {mean }}<V_{c}$ の領域を風騒音の影響域， $V_{c} \leqq V_{\text {mean }}$ の 領域を風騷音の支配域，また， $V_{e} ， V_{c}^{\prime}$ 風騒音の「影 響風速」,「支配風速」と呼ぶごとができる。 $V_{e}, V_{c}$ の 2 つの指標は，風騒音の居住性におよぼす影響範囲を定 量的に整理してゆくために，有意義なものと考えられる。

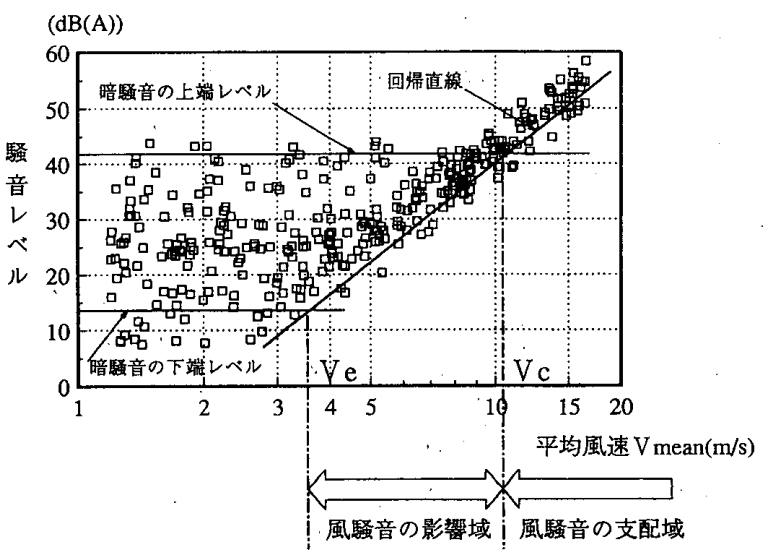

図一10 風騷音の影響域と支配域の概念図 
実測結果から $V_{e}, V_{c}$ を求めると,「建屋 C」の 3 室 では, ほぼ $V_{e}=4 \mathrm{~m} / \mathrm{s}, V_{c}=10 \mathrm{~m} / \mathrm{s}$, 「建屋 D」の 4 室 においては,室により暗騷音の上端レベルに差異があり， $V_{c}=13 \sim 17 \mathrm{~m} / \mathrm{s}$ となった。暗騒音の上端, 下端レベルは, $L_{\mathrm{eq}}$ の $5 \%$ および $95 \%$ 分布統計量を用いた。「建屋D」 においては, 暗騒音の下端レベルが, 騒音計の最低レン ジ以下となり， $V_{e}$ の算出はできなかった。

\section{2 風騒音の $N$ 值相当風速}

影響風速や支配風速は，室内暗騒音レベルにより変わ るものであり，風騒音の影響評価のため有意義である之 考えられるが，これとは別に，暗騒音レベルにはとらわ れずに，風騒音を一定の規準値と比較することが必要な 場合も考えられる。交通騒音や設備騷音などと同様に， 風騷音の低減・防止計画をあつかうためには，室内騒音 の規準値と風騒音の大小が問題になる。しかし，建築の 条件を定めても，風騷音は風の条件に依存する変動性の 騒音であるため, 規準値との単純な比較には意味がなく, 規準値を超える風騒音の発生頻度による評価が必要にな る。このためには，まず，規準値を超える風の条件を求 め，ついで，その条件を満たす風の発生率を推定する之 いう手順をとることが基本となる。後者の手順に対して は, 自然風に関する研究成果の適用が可能亡考え, ここ では, 前者の手順に対して必要な定量化のための指標に ついて検討する。

ある規準値を超える風騒音となる風の条件は，風騒音 に影響する変動風のパラメータによって定義される。こ のとき, 3 章の結果を参照すれば, 最も主要なパラメー 夕は平均風速であり，これにガストファクタあるいは乱 れの強さ，および風向（卓越風向からの偏差）が, 副次 的なものとして加わる形となる。簡単のため, 副次的な 影響を無視すると，ある規準值を超える風騒音となる風 の条件は, 平均風速によって定義できることになる。

室内騷音の規準值として, 日本建築学会規準の $N$ 值 による規定 ${ }^{8 /}$ 参照し，これに相当する風騒音となる風 速を「 $N$ 值相当風速 $\left.V_{N-* *}\right\rfloor$ と呼ぶことにする。 $N$ 值 はオクターブバンドごとの值で規定されているため， $N$ 值相当風速はオクターブバンドごとで求めた $V_{N-* *}$ の 最小値として定義される。これらの指標により規準値を 超える風騒音となる風の条件が定量化でき，風騒音の居 住性におよぼす影響評価に役立てることができる。また， オクターブバンドごとの $N$ 值相当風速によって, 風騒 音の周波数ごとの影響評価が可能になり, 対策を優先す べき周波数が明確に指摘できるようになる。

図一11 は,「建屋C」と「建屋 D」におけるオクター ブバンドごとのべき乗則を仮定した回帰直線を用いて， 日本建築学会規準の 1 級である $\mathrm{N}-30$ となる風速 $V_{N-30}$ を求めて, 比較したものである。「建屋C」の 3 室では, ほぼ $V_{N-30}=6 \mathrm{~m} / \mathrm{s}$,「建屋 D」の 4 室では, $V_{N-30}=11$

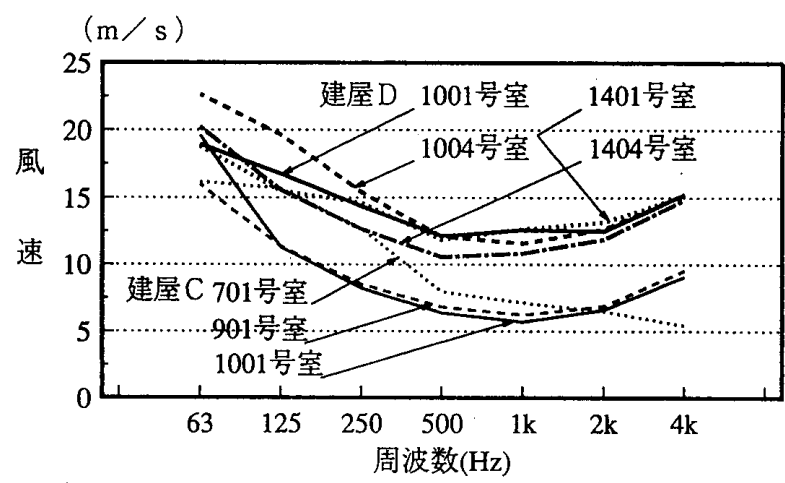

図一11 オクターブバンドごとの $N$ 値相当風速 $V_{N-30}$ の建屋, 室による差異

$12 \mathrm{~m} / \mathrm{s}$ となった。また， $N$ 值を規準とする場合， 250 $\mathrm{Hz}$ 以下の成分が，低減・防止対策上重要になる場合は 少ないようであることが分かる。また， $500 \mathrm{~Hz}$ 以上の 高音域では，同一建屋内の室による差異よりも建屋によ る差異が大きく表われているのに対し，これより低音域 では, 室による差異と建屋による差異が同程度になって いることが分かる。

本節および $3.4,3.5$ では, 風騒音の建屋や室位置に よる差異の実測結果を示した。これにより，高層集合住 宅における風騒音の実態の一端が知られ，その概略傾向 が明らかになったものと考えられる。ただし，風騒音に およぼす建築的要因の影響を,すべて含んだ形で比較し ているため, 各要肉の効果を定量化することが今後の課 題となっている。

\section{5. まとめ}

高層集合住宅における風騒音の実態を，10１4 階建 ての 4 つの建屋における実測調査により明らかにし，そ の大きさの程度と物理的特性の概要について検討した。

その結果をまとめると，以下のようになる。

(1) 室内における 10 分平均の等価騒音レベル $L_{\mathrm{eq}}$ と風 速の時間平均を長時間にわたり連続計測した結果, 平均 風速 $V_{\text {mean }}$ と $L_{\mathrm{eq}}$ とに強い相関のある部分が認められ, 風によって発生していると考えられる騒音，すなわち風 騒音の存在が確認された。

(2) 風騒音の $L_{\mathrm{ea}}$ と $V_{\text {mean }}$ の間には, $(6)$ 式のベき乗 則が成り立ち，風騒音の発生機構に関連したべき指数 $\alpha$ 之, 発生源の強度や伝搬系の減衰性状を表わす定数項 $L_{k}+$ 風の変動性の関連を表す定数項 $L_{\mathrm{cor}}$ により整理さ れることを示した。実測結果もこの傾向を示し,オクター ブバンドごとの $L_{\mathrm{eq}}$ でも, この傾向が明瞭に現われてい る。

(3) 風速変動を代表するパラメータとしてガストファク 夕を用い, 実測結果を検討したところ, 風騒音の $L_{\mathrm{eq}}$ に 対するガストファクタの影響はあるものの, パラメータ の実際的な範囲では，その影響は大きなものではないこ 
とが分かった。

(4) 同一建屋内での室位置による風騒音の差異に関して は, 風上側最上階を含む鉛直方向では, 最上階より下層 4 階程度を対象とした場合, 風騒音に余り大きな差異が 生じないことが分かった。

(5) 4 つの建屋における風騒音の実測結果を比較する と, 最大のものと最小のものとで, 平均風速 $10 \mathrm{~m} / \mathrm{s}$ の ときに平坦特性で $18 \mathrm{~dB}, \mathrm{~A}$ 特性で $14 \mathrm{~dB}(\mathrm{~A})$ の差異が あった。

さらに, 風騒音が居住性におよぼす影響の現われ方を， 実測結果から考察し, 風騒音の影響評価を行うための指 標として，以下を提案した。

・「影響風速 $V_{e}$ 」および「支配風速 $V_{c}$ 」 : 風騒音が室内 暗騒音の下端レベルを越え，はじめて室内に物理的影響 を及ぼし始める風速 $\left(V_{e}\right)$ ，および，風騒音が室内騒音 の主要な音源になり，室内の音環境を支配するようにな る風速 $\left(V_{c}\right)$ 。

- $\left\lceil N\right.$ 值相当風速 $\left.V_{N-* *}\right\rfloor$ : 風騒音が, 室内騒音に関す る日本建築学会の規準值と等しいレベルになる風速。

本報で示した実测結果は，建築条件が異なる4つの集 合住宅での単一風向の条件下でのものである。今後さら に; 風向と風騒音の関係, 建築的要因の風騒音に及ぼす 影響の定量化などを検討して行く必要がある。

\section{謝 辞}

本研究について, 京都大学 古江嘉弘助教授よりご助 言頂いたことを,ここ記して感謝いたします。

\section{本論文に関連した既発表論文}

1）吉岡 清, 須田健一, 安藤 充: “高層集合住宅の風騒音 に関する実測調查”, 日本建築学会大会学術講演梗概集 (D), pp. $315 \sim 316,1987$

2）須田健一, 吉岡 清, : “高層集合住宅における風騒音の 実測調查”, 日本風工学会誌 41, pp. 9 10, 1989

3）吉岡 清, 須田健一：“高層集合住宅における風騒音に関 する実測調查 (その2) 室内の騒音と風のパラメータの
関係について”，日本建築学会大会学術講演梗概集（D）, pp. 401 402, 1990

4）吉岡 清, 須田健一：“高層集合住宅における風騒音に関 する実測調查（その3）風騒音の影響風速と支配風速”, 日本建築学会大会学術講演梗概集 (D), pp. 435 436, 1991

5）吉岡 清, 須田健一：“高層集合住宅のバルコニー手すり からの風騒音発生に関する実測調查”, 騒音制御工学会技 術発表会論文集, pp. 109 112, 1991

6）須田健一, 吉岡 清, : “高層集合住宅における風騒音の 実測調査（その2 バルコニー手すりからの風騒音の発 生)”，日本風工学会誌 47, pp. $49 \sim 50,1991$

7）吉岡 清, 須田健-- : “高層集合住宅における風騒音に関 する実测調查 (その4) 建屋による風騒音の差異の概略 的傾向”, 日本建築学会大会学術講演梗概集 (D), pp. 137 138, 1992

\section{参考文献}

1）村上周三ほか 4 名：“超高層集合住宅のバルコニーの風環 境に関する住民の意識調査”, 日本建築学会大会学術講演 梗概集（D)，pp. 299 -303，1986

2) Berhault, J.P.A. : "Wind Noise in Buildings", Wind Engineering 1(1), pp. 67 82, 1977

3）板本守正: “ガラリ・手すりの風切り音”, 騒音制御 6(4), pp. 188 190, 1982

4）十倉 毅, 和木孝男, 西村宏昭: “建物手すりによる風騒 音の実験的検討”, 日本建築学会大会学術講演梗概集（計 画系), pp. 83 84, 1984

5）西村宏昭：“アルミニウム合金製手すり子の風による振動 に関する風洞実験”, GBRC, 38, pp. 42〜47, 1985 .

6) Lighthill, M.J. : “On sound generated aerodynamically, I. General theory”, Proc. R. Soc. London, A211, pp. $564 \sim 587,1952$

7）塩谷正雄：「強風の性質」, 開発社, 1979

8）日本建築学会編：「建築物の遮音性能規準と設計指針】, 技報堂出版, 1979

(1992 年 10 月 2 日原稿受理, 1993 年 4 月 15 日採用決定) 